\title{
Articles
}

\section{Political Corruption as a Regulatory Problem in Germany}

\author{
By Sebastian Wolf
}

The shortcomings identified in German bribery law-such as the limited criminalization of bribery of parliamentarians and other members of domestic assemblies, coupled with the absence of trading in influence offenses, and furthermore, certain limits in the criminalization of bribery of foreign and international officials and of private sector bribery-represent significant lacunae in the law. ${ }^{1}$

\section{A. Introduction}

The European Union and 164 states have ratified the United Nations Convention against Corruption (UNCAC), but Germany has not. ${ }^{2}$ Forty-two out of forty-seven member states of the Council of Europe have ratified the Criminal Law Convention on Corruption (CLCOC), but Germany has not. ${ }^{3}$ Why has Germany signed but not yet implemented and ratified these two important international anti-corruption instruments adopted nearly ten yearsUNCAC-or fourteen years-CLCOC-ago? The Bundesregierung (Federal Government) has promised numerous times to fully comply with international anti-corruption treaties. ${ }^{4}$ Germany's poor ratification record regarding instruments such as UNCAC is increasingly

\footnotetext{
* The author is a postdoctoral researcher at the University of Konstanz (Konstanz, Germany) and the Liechtenstein-Institut (Bendern, Liechtenstein). Email: sebastian.wolf@uni-konstanz.de. He thanks Elisa Hoven for the invitation to submit this article and the student editors for improving the text.

${ }^{1}$ Grp. of States Against Corruption (GReCO), Third Evaluation Round Interim Compliance Report on Germany, 6 , para. $20 \quad$ (2012), available at http://www.coe.int/t/dghl/monitoring/greco/evaluations/round3/GrecoRC3\%282012\%2915_Germany_Interim_E N.pdf.

${ }^{2}$ United Nations Office on Drugs \& CRIME (UNODC), UNCAC Signature ANd Ratification Status (2013), available at http://www.unodc.org/unodc/en/treaties/CAC/signatories.html.

3 Council of Europe, Treaty Office, ClCOC Signature And Ratification Status (2013), available at http://www.conventions.coe.int/Treaty/Commun/ChercheSig.asp?NT=173\&CM=8\&DF=25/02/2013\&CL=ENG.

${ }^{4}$ For example at the G8 Summit 2007 in Heiligendamm, see The Group of EIGHT, CHAIR'S SUMmARY: HeILIGENDAMm (June $\quad 8$ 2007), http://www.g-8.de/Content/EN/Artikel/_g8-summit/anlagen/chairssummary, templateld=raw, property=publicationFile.pdf/chairs-summary. pdf.
} 
embarrassing for German politics and is criticized by other countries and international organizations. $^{5}$

The main obstacle to the ratification of both anti-corruption conventions is the existing criminal offense of bribery of members of parliament. Remarkably, the legal situation regarding this criminal offense has not changed since the author wrote about outstanding reforms of German anti-bribery law in this journal six years ago. ${ }^{6}$ This article will focus on the adequate criminalization of corruption of parliamentarians as a regulatory problem in Germany. The next section outlines the legal status quo (B). Then, the standards of international anti-corruption instruments regarding the bribery of members of domestic assemblies are briefly described (C). The next section mainly deals with recent political developments and discussions (D). The concluding section assumes, inter alia, that a respective reform of German criminal law could take place after the upcoming federal election (E).

\section{B. Criminalization of Bribery of Parliamentarians: The Legal Status Quo in Germany}

For several decades, active and passive bribery of members of parliament was not criminalized at all in Germany. The criminal law provisions on bribery of public officials did not (and still do not) apply to parliamentarians: Under German criminal law, members of parliaments are not Amtsträger (public officials). ${ }^{7}$ As late as in 1993, the Bundestag (lower house of the German Federal Parliament) adopted a law that added Sect. 108e to the StGB: 8

\section{Bribery of a Member of Parliament}

(1) Whoever undertakes to buy or sell a vote for an election or ballot in the European Parliament or in a representative body of the Federation, of the Länder, of the municipalities or associations of municipalities

\footnotetext{
${ }^{5}$ See, e.g., Wolfgang Jäckle, Eine deutsche Peinlichkeit, SüddeUtSCHE ZeITUng, Jan. 15, 2012, at 2.

${ }^{6}$ Sebastian Wolf, Modernization of the German Anti-Corruption Criminal Law: The Next Steps, 8 German L.J. 295 (2007).

${ }^{7}$ Strafgesetzbuch [StgB] [Penal Code], § 11, para. 1, no. 2 (Ger.).

${ }^{8}$ Strafgesetzbuch [StgB] [Penal Code], Jan. 22, 1994, Bundesgesetzblatt (BGBl. I) 3322, § 108e (Ger.). The amendment entered into force as of 22 January 1994. On the history of the criminal offense of bribery of parliamentarians in Germany, see URSULA EPP, Die ABGEORDNETENBESTECHUNG: § 108E STGB (1997); Manfred Ernst Möhrenschlager, Die Struktur des Straftatbestandes der Abgeordnetenbestechung auf dem Prüfstand: Historisches und Künftiges, in FESTSCHRIFT FÜR ULRICH WEBER 217 (Bernd Heinrich, Eric Hilgendorf, Wolfgang Mitsch \& Detlev Sternberg-Lieben eds., 2004).
} 
shall be punished with imprisonment not exceeding five years or with a fine.

(2) In addition to imposing a sentence of imprisonment for a criminal offense under Subsection 1 the court may deprive the convicted offender of the capacity to acquire rights ensuing from public elections and of the right to vote or cast a ballot in public matters. ${ }^{9}$

The new criminal offense was criticized from the start. ${ }^{10}$ It only applies to very few actions by parliamentarians-buying or selling of a vote for an election or ballot-and in very few places-parliamentary assemblies or their committees, but not, e.g., the respective parliamentary groups. Moreover, it has a narrow notion of undue benefits, only money; does not cover payments to third persons; and does not criminalize bribes for past actions or attempted bribery of members of parliament. ${ }^{11}$

In 1997, the provisions regarding active and passive bribery of public officials ${ }^{12}$ were significantly sharpened by the Gesetz zur Bekämpfung der Korruption (Act for the Fight against Corruption). ${ }^{13}$ However, Sect. 108 e StGB was not reformed. ${ }^{14}$ Shortly thereafter, the anti-bribery convention of the Organization for Economic Co-operation and Development (OECD Convention) ${ }^{15}$ was ratified and implemented by the Gesetz zur

\footnotetext{
${ }^{9}$ The Organisation for Economic Co-Operation and DeVelopment (OECD), EXcerpts from the CRiminal Code (StgB) of the Federal Republic of Germany (Unofficial Translation) Sect. 108(e), available at http://www.oecd.org/daf/antibribery/anti-briberyconvention/2377370.pdf.

${ }^{10}$ See, e.g., Stephan Barton, Der Tatbestand der Abgeordnetenbestechung (\$108e StGB), 47 NEUE JURISTISCHE WOCHENSCHRIFT [NJW] 1098 (1994).

11 For a harsh critique, see Hans Herbert von Arnim, Der gekaufte Abgeordnete: Nebeneinkünfte und Korruptionsproblematik, 25 NeUE ZEITSCHRIFT für VeRWALTUNGSRECHT [NVWZ] 249 (2006). For some illustrative examples of bribery not covered by the current Sect. 108e StGB, see Elisa Hoven, Die Strafbarkeit der Abgeordnetenbestechung. Wege und Ziele einer Reform des $\S 108$ e StGB, 8 ZEITSCHRIFT FÜR INTERNATIONALE STRAFRECHTSDOGMATIK [ZIS] 33, 35 (2013).

${ }^{12}$ Strafgesetzbuch [StGB] [Penal Code], §§ 331-335 (Ger.).

${ }^{13}$ See Bernd Heinrich, Rechtsprechungsüberblick zu den Bestechungsdelikten (\$§ 331-335 StGB), 25 NEUE ZEITSCHRIFT FÜR STRAFRECHT [NSTZ] 197 (2005) for numerous references regarding the Gesetz zur Bekämpfung der Korruption.

${ }^{14}$ Sebastian Wolf, Parlamentarische Blockade bei der Korruptionsbekämpfung? Zur verschleppten Neuregelung des Straftatbestandes der Abgeordnetenbestechung, 39 ZEITSCHRIFT FüR PARLAMENTSFRAGEN [ZPARL] 493, 496 (2008).

15 The Organisation for Economic Co-operation and DeVelopment (OECD), Convention on Combating Bribery of FoREIGN PUBLIC OfFICIALS IN INTERNATIONAL BUSINESS TRANSACTIONS, available with other OECD anti-bribery instruments at http://www.oecd.org/daf/anti-bribery/anti-briberyconvention/ConvCombatBribery_ENG.pdf. For the most
} 
Bekämpfung internationaler Bestechung (IntBestG-Act for the Fight Against International Bribery). ${ }^{16}$ The IntBestG mainly expanded the scope of application of some parts of German anti-bribery law to foreign public officials and officials of international organizations. ${ }^{17}$ Due to the broad definitions of the act of bribery as well as "foreign public official" in Art. 1 para. 1 and para. 4(a) of the OECD Convention, it was not possible to simply enact a reference norm ${ }^{18}$ referring to Sect. 108 e StGB with regard to members of foreign parliaments. Thus, a specific provision dealing with foreign parliamentarians and members of international parliamentary assemblies was established:

\section{Bribery of Foreign Members of Parliament in Connection with International Business Transactions}

(1) Anyone who offers, promises or grants to a Member of a legislative body of a foreign state or to a Member of a parliamentary assembly of an international organization an advantage for that Member or for a third party in order to obtain or retain for him/herself or a third party business or an unfair advantage in international business transactions, in return for the Member's committing an act or omission in future in connection with his/her mandate or functions, shall be punished by imprisonment not exceeding five years or by a fine.

(2) The attempt shall incur criminal liability. ${ }^{19}$

Again, the legislative opportunity for criminal law reform in the anti-corruption sector was not used to amend Sect. 108e StGB. Thus, since 1999, different criminal law standards

comprehensive analysis of this convention, see THE OECD CONVENTION ON BRIBERY: A COMMENTARY (Mark Pieth, Lucinda A. Low \& Peter J. Cullen eds., 2007).

${ }^{16}$ See Matthias Korte, Der Einsatz des Strafrechts zur Bekämpfung der internationalen Korruption, 18 ZEITSCHRIFT FÜR WIRTSCHAFTS UND STEUERSTRAFRECHT [WISTRA] 81, 86-88 (1999). The EU-Bestechungsgesetz, enacted at the same time, penalized bribery of public officials of both Member States of the European Union (EU) and EU institutions. EU-Bestechungsgesetz [EUBESTG] [EU Anti-Corruption Act]; see Korte, supra note 16, at 83-85.

${ }^{17}$ Sebastian Wolf, Modernization of the German Anti-Corruption Criminal Law by International Legal Provisions, 7 GERMAN L.J. 785, 789 (2006).

${ }^{18}$ Cf. id. at 786 .

19 The Organisation for Economic Co-operation and DeVelopment (OECD), Act on Combating Bribery of Foreign Public Officials in International Business Transactions (Unofficial Translation) Art. 2, Sect. 2, available at http://www.oecd.org/daf/anti-bribery/anti-briberyconvention/2377209.pdf. 
have existed for bribery of domestic and foreign members of parliament. ${ }^{20}$ The domestic $^{2}$ critique regarding the shortcomings of Sect. 108e StGB culminated in a judgment of the Bundesgerichtshof (Federal Court of Justice) that frankly asked the legislature for a revised criminal law covering more corrupt actions of parliamentarians. ${ }^{21}$

\section{Bribery Involving Members of Parliament: The Standards of International Anti- Corruption Instruments}

After the Gesetz zur Bekämpfung der Korruption, all amendments of German anticorruption criminal law were induced by international legal provisions. ${ }^{22}$ However, the criminal offense of bribery of domestic members of parliament has not been amended thus far. There are two anti-corruption treaties-signed by Germany many years ago (see A) - that call for a reform of Sect. 108e StGB: The UNCAC ${ }^{23}$ and the CLCOC. ${ }^{24}$ Anti-bribery instruments by the European Union and the OECD do not necessarily require respective amendments of the German criminal law. ${ }^{25}$ The UNCAC provides:

Bribery of national public officials

Each State Party shall adopt such legislative and other measures as may be necessary to establish as criminal offenses, when committed intentionally:

\footnotetext{
${ }^{20}$ Wolf, supra note 17 , at 790.

${ }^{21}$ Bundesgerichtshof [BGH-Federal Court of Justice], Case No. 5 StR 453/05, 51 ENTSCHEIDUNGeN DES BUNDESGERICHTSHOFES IN STRAFSACHEN [BGHST] 44 (May 9, 2006), http://dejure.org/dienste/vernetzung/rechtsprechung?Text=5\%20StR\%20453\%2F05\&Suche=5\%20StR\%20453\%2 F05.

${ }^{22}$ On the internationalization of German anti-corruption law, see Wolf, supra notes 6 and 17. For comprehensive analyses, see, e.g., the following dissertations: IOANNIS N. ANDROULAKIS, DIE GLOBALISIERUNG DER KoRRUPTIONSBEKÄMPFUNG (2007); ANNA-CATHARINA MARSCH, StRUKTUREN DER INTERNATIONALEN KORRUPTIONSBEKÄMPFUNG. WIE WIRKSAM SIND INTERNATIONALE ABKOMMEN? (2010); SIMONE NAGEL, ENTWICKLUNG UND EFFEKTIVITÄT INTERNATIONALER MAßNAHMEN ZUR KORRUPTIONSBEKÄMPFUNG (2007).

${ }^{23}$ United Nations Convention Against Corruption, Oct. 31, 2003, 2349 U.N.T.S. 41 [hereinafter UNCAC], available at http://www.unodc.org/documents/treaties/UNCAC/Publications/Convention/08-50026_E.pdf. On the UNCAC, see, e.g., Philippa Webb, The United Nations Convention Against Corruption: Global Achievement or Missed Opportunity?, 8 J. INT'L ECON. L. 191 (2005); Die KonVENTION DER VEREINTEN NATIONEN ZUR BEKÄMPFUNG DER KoRRUPTION. Betrachtungen aus Wissenschaft Und Praxis (Rainer Hofmann \& Christina Pfaff eds., 2006).

${ }^{24}$ Criminal Law Convention On Corruption, Jan. 27, 1999, C.E.T.S. No. 173 [hereinafter CLCOC], available at http://www.conventions.coe.int/Treaty/en/Treaties/Html/173.htm.

${ }^{25}$ Wolf, supra note 14 , at 496 .
} 
(a) The promise, offering or giving, to a public official, ${ }^{26}$ directly or indirectly, of an undue advantage, for the official himself or herself or another person or entity, in order that the official act or refrain from acting in the exercise of his or her official duties;

(b) The solicitation or acceptance by a public official, directly or indirectly, of an undue advantage, for the official himself or herself or another person or entity, in order that the official act or refrain from acting in the exercise of his or her official duties. ${ }^{27}$

In a specific provision dealing with domestic parliamentarians, the CLCOC provides:

\section{Bribery of members of domestic public assemblies}

Each Party shall adopt such legislative and other measures as may be necessary to establish as criminal offenses under its domestic law the conduct referred to in Articles $2^{28}$ and $3,^{29}$ when involving any person who is a member of any domestic public assembly exercising legislative or administrative powers. ${ }^{30}$

While Art. 15 UNCAC is a legally binding norm, states may declare full or partial reservations regarding Art. $4 \mathrm{CLCOC}$, according to Art. $37 \mathrm{CLCOC}^{31}$ However, GRECO-an

\footnotetext{
${ }^{26}$ According to UNCAC Art. 2(a), "'Public official' shall mean: (i) any person holding a legislative ... office of a State Party, whether appointed or elected, whether permanent or temporary, whether paid or unpaid, irrespective of that person's seniority...."

${ }^{27}$ UNCAC Art. 15.

28 "Each Party shall adopt such legislative and other measures as may be necessary to establish as criminal offenses under its domestic law, when committed intentionally, the promising, offering or giving by any person, directly or indirectly, of any undue advantage to any of its public officials, for himself or herself or for anyone else, for him or her to act or refrain from acting in the exercise of his or her functions." CLCOC Art. 2.

29 "Each Party shall adopt such legislative and other measures as may be necessary to establish as criminal offenses under its domestic law, when committed intentionally, the request or receipt by any of its public officials, directly or indirectly, of any undue advantage, for himself or herself or for anyone else, or the acceptance of an offer or a promise of such an advantage, to act or refrain from acting in the exercise of his or her functions." CLCOC Art. 3.

${ }^{30}$ CLCOC Art. 4.

31 "Any State may, at the time of signature or when depositing its instrument of ratification, acceptance, approval or accession, reserve its right not to establish as a criminal offence under its domestic law, in part or in whole, the
} 
intergovernmental monitoring body of the Council of Europe in the field of anticorruption-evaluates the implementation of Art. $4 \mathrm{CLCOC}$, even with regard to GRECO member states that have not ratified CLCOC yet. ${ }^{32}$ Given the narrow scope of Sect. 108e StGB outlined above, ${ }^{33}$ it is obvious that the current criminal offense of bribery of domestic parliamentarians does not meet the requirements of Art. 15 UNCAC $^{34}$ and Art. $4 \mathrm{CLCOC}^{35}$ The following section briefly explains why the high legal adaptation pressure has not resulted in a successful amendment of German criminal law to date.

\section{Recent Political Developments and Discussions}

In 2007, Thomas Weigend assumed that the Bundestag had not adapted Sect. 108e StGB to meet international requirements because its members had been too busy working on so many important laws. ${ }^{36}$ Obviously, this is not true. Several parliamentarians-especially politicians of the Christlich Demokratische Union (CDU: Christian Democratic Union) and the Freie Demokratische Partei (FDP: Free Democratic Party)-oppose a stricter criminal offense of bribery involving members of domestic assemblies. ${ }^{37}$ They already opposed the drafting of the broad UNCAC definitions of "public official" and the act of bribery outlined above. ${ }^{38}$ Due to the CDU's and FDP's reluctance, there was no draft law regarding a reform of Sect. 108e StGB that was capable of winning a parliamentary majority in the last legislative period (2005-2009). Respective bills by Bündnis 90/Die Grünen (B'90/Die Grünen: Alliance 90/The Greens) ${ }^{39}$ and Die Linke (The Left Party) ${ }^{40}$ were not adopted by

conduct referred to in Articles 4, 6 to 8, 10 and 12 or the passive bribery offences defined in Article 5." CLCOC Art. 37 , para. 1.

${ }^{32}$ GRECO, supra note 1.

${ }^{33}$ See supra Part B.

${ }^{34}$ To name just one of the most cited references: Anne van Aaken, Genügt das deutsche Recht den Anforderungen an die VN-Konvention gegen Korruption? Eine rechtsvergleichende Studie zur politischen Korruption unter besonderer Berücksichtigung der Rechtslage in Deutschland, 65 ZEITSCHRIFT FÜR AUSLÄNDISCHES ÖFFENTLICHES RECHT UND VÖLKERRECHT [ZAÖRV] 425, 430 (2005).

35 Grp. of States against Corruption (Greco), third Evaluation Round evaluation Report on Germany on INCRIMINATIONS, 30, para. 107 (2009), available at http://www.coe.int/t/dghl/monitoring/greco/evaluations/round3/GrecoEval3\%282009\%293_Germany_One_EN. pdf. See also GRECO, supra note 1.

${ }^{36}$ Thomas Weigend, Internationale Korruptionsbekämpfung: Lösung ohne Problem?, in FESTSCHRIFT FÜR GÜNTHER JAKOBS 747, 753 (Michael Pawlik \& Rainer Zaczyk eds., 2007).

${ }^{37}$ Wolf, supra note 14 , at 502.

${ }^{38}$ See supra Part C; Möhrenschlager, supra note 8, at 230.

${ }^{39}$ Wolf, supra note 14 , at 499. 
the parliament. Nevertheless, a study by the Wissenschaftliche Dienste des Bundestages (Scientific Services of the Bundestag) emphasized the need to reform Sect. 108e StGB. ${ }^{41}$

During the current legislative period (2009-2013), several organizations and political actors have called for a stricter criminal offense of bribery of parliamentarians. GRECO reported, inter alia, that Sect. 108e StGB does not meet the requirements of Art. $4 \mathrm{CLCOC}^{42}$ and started a non-compliance procedure against Germany due to its general inactivity in implementing the anti-corruption provisions of the Council of Europe. ${ }^{43}$ In a joint letter, thirty-seven chief executive officers of large German companies urged all parliamentary groups of the Bundestag to ratify the UNCAC and implement its provisions as soon as possible. $^{44}$ Three non-governmental organizations (Campact, Lobby Control, and Transparency International Germany) collected more than 60,000 signatures demanding the adoption of several anti-corruption measures, including a stricter criminalization of bribery of members of parliament. ${ }^{45}$ In an unusual move, the president of the Bundestag, Norbert Lammert, has called for ratification of the UNCAC and submitted an informal proposal to reform Sect. 108 e StGB. ${ }^{46}$ Moreover, the ministers of justice of the German Länder (states) have assigned the government of North Rhine-Westphalia to draft a law to

${ }^{40}$ Id. at 500 .

${ }^{41}$ Ariane Schenk, Rechtsfragen im Kontext der Abgeordnetenkorruption, WISSENSCHAFTLICHE DIENSTE DES DEUTSCHEN BUNDESTAGES, Ausarbeitung WD 7-3000-148/08 (2008), available at https://netzpolitik.org/wpupload/Abgeordnetenkorruption.pdf. Remarkably, the administration of the Bundestag has not published this study yet and tried to prevent its publication by a private website. See Sebastian Wolf, Regulierungsproblem Abgeordnetenbestechung: eine Analyse neuerer Entwicklungen, 6 CORPORATE COMPLIANCE ZEITSCHRIFT [CCZ] 99, 100 (2013).

${ }^{42}$ GRECO, supra note 35 .

${ }^{43}$ Grp. of States Against Corruption (GRECO), Third Evaluation Round Compliance Report on Germany, 16, para. 75 (2011), available

http://www.coe.int/t/dghl/monitoring/greco/evaluations/round3/GrecoRC3\%282011\%299_Germany_EN.pdf.

44 ICC Deutschland, ICC Deutschland setzt sich für UN-Antikorruptionskonvention ein (2012), available at http://www.icc-deutschland.de/news/429-icc-deutschland-setzt-sich-fuer-un-antikorruptionskonventionein.html.

45 Lobby Control, Transparenz vertagt? Aktion gegen Verschleierung von Nebeneinkünften und Abgeordnetenbestechung (2012), available at http://www.lobbycontrol.de/2012/10/transparenz-vertagtaktionen-gegen-verschleierung-von-politiker-nebeneinkunften-und-abgeordnetenbestechung/.

${ }^{46}$ Claudia Kade, Lammert allein im Kampf gegen die Korruption, FINANCIAL TIMES DeUTSCHLAND ONLINE (2012), available at http://www.ftd.de/politik/europa/:positionspapier-vom-parlamentspraesident-lammert-allein-imkampf-gegen-die-korruption/70115633.html. 
amend Sect. 108e StGB via the Bundesrat (upper house of the German Federal Parliament). ${ }^{47}$

The three opposition parties in the Bundestag-Sozialdemokratische Partei (SPD: Social Democratic Party), B'90/Die Grünen and Die Linke-have submitted separate bills proposing to reform the criminal offense of bribery of parliamentarians. ${ }^{48}$ The proposals are fairly similar in regard to their key elements: Principally, they extend the scope of application of the criminal offense to all actions of a parliamentarian in the exercise of his or her mandate. Certain moderate advantages for specific legitimate actions are not prohibited. The bill of Die Linke, based on Sect. 331-334 StGB, is the most far-reaching proposal, while the draft law submitted by the SPD contains the most exceptions. The Greens suggest to also cover bribery involving candidates for parliament in their proposed law. ${ }^{49}$ In October 2012, an expert hearing convened by the Bundestag's Committee on Legal Affairs demonstrated the usual arguments for and against amending Sect. 108e StGB. ${ }^{50}$ Opponents of a stricter criminal offense argued, inter alia, that there was no factual or legal need for a reform; that the bills submitted by the opposition parties violated the constitutional requirement of clarity and definiteness; ${ }^{51}$ that the proposals criminalized the legitimate behavior of parliamentarians because members of parliament enjoy a special status; ${ }^{52}$ and that a stricter Sect. 108 e StGB could be misused as an unfair weapon in political competition. ${ }^{53}$ Proponents of a reform rejected these critiques arguing, inter alia, that the draft laws were necessary, lawful, and appropriate. ${ }^{54}$

47 NRW-Minister zur Korruptionsbekämpfung, LEGAL TRIBUNE ONLINE (2013), available at http://www.Ito.de/recht/nachrichten/n/nrw-justizminister-kutschaty-abgeordnetenbestechung-gesetzentwurf/.

\footnotetext{
48 Deutscher Bundestag: Drucksachen und Protokolle [Bt-Drs.] 17/1412 (Ger.); Deutscher Bundestag: Drucksachen Und Protokolle [BT-Drs.] 17/5933 (Ger.); Deutscher Bundestag: Drucksachen und Protokolle [BT-DRs.] 17/8613 (Ger.), available

http://www.bundestag.de/bundestag/ausschuesse17/a06/anhoerungen/archiv/27_Bek_mpfung_Abgeordneten bestechnung/index.html.

49 For more comprehensive analyses of the bills, see Hoven, supra note 11; Wolfgang Jäckle, Abgeordnetenkorruption und Strafrecht: Eine unendliche Geschichte?, 45 ZEITSCHRIFT FÜR RECHTSPOLITIK [ZRP] 97 (2012); Eric Schnell, Neuer Anlauf zur Bekämpfung der Abgeordnetenbestechung?, 44 ZEITSCHRIFT FÜR RECHTSPOLITIK [ZRP] 4 (2011). See also infra notes 53 and 54.

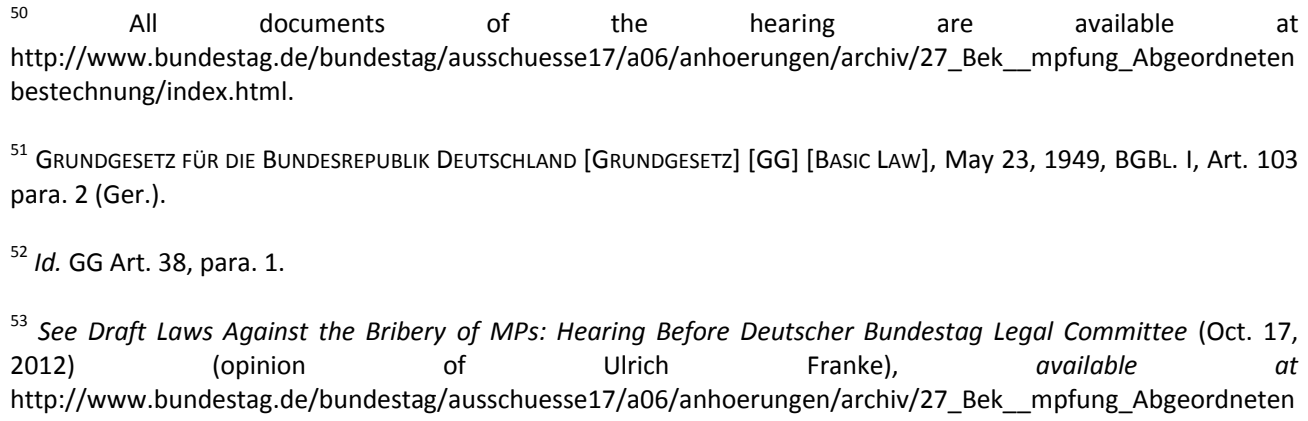




\section{E. Conclusion and Outlook}

This article showed that the current criminal offense of bribery of domestic parliamentarians in Germany does not comply with international anti-corruption standards. Therefore, Germany has not ratified two important anti-corruption treaties (CLCOC and UNCAC) despite years of opportunity to do so. Thus far, certain politicians of the CDU and FDP have opposed reforming Sect. 108e StGB, and some legal experts share their opinions. When analyzing this case from the perspective of multi-level politics, it seems that institutional veto points ${ }^{55}$ or veto players ${ }^{56}$ in the national parliament have been more important than high legal adaptation pressure.

bestechnung/04_Stellungnahmen/Stellungnahme_Dr_Franke.pdf; Draft Laws Against the Bribery of MPs: Hearing Before Deutscher Bundestag Legal Committee (Oct. 17, 2012) (opinion of Klaus Ferdinand Gärditz), available

http://www.bundestag.de/bundestag/ausschuesse17/a06/anhoerungen/archiv/27_Bek_mpfung_Abgeordneten bestechnung/04_Stellungnahmen/Stellungnahme_G_rditz.pdf; Draft Laws Against the Bribery of MPs: Hearing Before Deutscher Bundestag Legal Committee (Oct. 17, 2012) (opinion of Gerald Kretschmer), available at http://www.bundestag.de/bundestag/ausschuesse17/a06/anhoerungen/archiv/27_Bek_mpfung_Abgeordneten bestechnung/04_Stellungnahmen/Stellungnahme_Kretschmer.pdf; Draft Laws Against the Bribery of MPs: Hearing Before Deutscher Bundestag Legal Committee (Oct. 17, 2012) (opinion of Cyrill-A. Schwarz), available at http://www.bundestag.de/bundestag/ausschuesse17/a06/anhoerungen/archiv/27_Bek_mpfung_Abgeordneten bestechnung/04_Stellungnahmen/Stellungnahme_Schwarz.pdf. See also Draft Laws Against the Bribery of MPs: Hearing Before Deutscher Bundestag Legal Committee (Oct. 17, 2012) (minutes of hearing), available at http://www.bundestag.de/bundestag/ausschuesse17/a06/anhoerungen/archiv/27_Bek_mpfung_Abgeordneten bestechnung/05_Wortprotokoll.pdf. For a short summary of the opinions, see Wolf, supra note 41, at 102.

${ }^{54}$ See Draft Laws Against the Bribery of MPs: Hearing Before Deutscher Bundestag Legal Committee (Oct. 17, 2012) (opinion of Heindich), available at http://www.bundestag.de/bundestag/ausschuesse17/a06/anhoerungen/archiv/27_Bek__mpfung_Abgeordneten bestechnung/04_Stellungnahmen/Stellungnahme_Heinrich.pdf; Draft Laws Against the Bribery of MPs: Hearing Before Deutscher Bundestag Legal Committee (Oct. 17, 2012) (opinion of Wolfgang Jäckle), available at http://www.bundestag.de/bundestag/ausschuesse17/a06/anhoerungen/archiv/27_Bek_mpfung_Abgeordneten bestechnung/04_Stellungnahmen/Stellungnahme_J_ckle.pdf; Draft Laws Against the Bribery of MPs: Hearing Before Deutscher Bundestag Legal Committee (Oct. 17, 2012) (opinion of Sebastian Wolf), available at http://www.bundestag.de/bundestag/ausschuesse17/a06/anhoerungen/archiv/27_Bek_mpfung_Abgeordneten bestechnung/04_Stellungnahmen/Stellungnahme_Wolf.pdf. See also the minutes of the hearing, supra note 53, and the brief summary by Wolf, supra note 41 , at 102 .

${ }^{55}$ Cf. Markus Haverland, National Adaptation to European Integration: The Importance of Institutional Veto Points (European Univ. Inst., Working Paper RSC No. 99/17, 1999), available at http://cadmus.eui.eu/bitstream/handle/1814/1622/99_17t.htm?sequence=1.

${ }^{56}$ George TSEbelis, Veto Players: How Political Institutions Work (2002). 
In March 2013, in a surprising move, parliamentarians of the CDU, SPD, B'90/Die Grünen, and Die Linke presented a common proposal to amend Sect. $108 \mathrm{e}$ StGB. ${ }^{57}$ It seemed that the protests of business, civil society, and international organizations had finally convinced at least some parts of the CDU to act. The proposed amendment would extend the application of the criminal offense to all actions of a member of parliament in the exercise of his or her mandate. ${ }^{58}$ Undue advantages given to third persons are covered by the proposal. Benefits permitted by law (e.g. permissible donations under Sect. 44a Abgeordnetengesetz (Act on Members of the Bundestag)) are not prohibited. The revised criminal offense shall apply to members of German parliaments at local, regional, and national levels as well as foreign parliaments and parliamentary assemblies of international organizations. The proposal does not cover benefits for past actions and attempted bribery of members of parliament: These elements are not necessarily required by CLCOC and UNCAC. $^{59}$

If the new proposal had been adopted by the Bundestag, both the CLCOC and the UNCAC could finally have been ratified. ${ }^{60}$ Additionally, the questionable unequal treatment of bribery of domestic and foreign parliamentarians would have been abolished. The FDP and the bulk of the CDU parliamentary group, ${ }^{61}$ however, prevented a reform of Sect. 108e StGB in the current legislative period. ${ }^{62}$ CDU representative Siegfried Kauder-chair of the

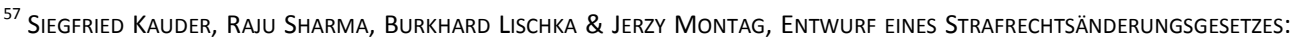
BEKÄMPFUNG DER KORRUPTION VON MANDATSTRÄGERN (2013), available at http://blog.abgeordnetenwatch.de/wpcontent/uploads/2013/03/2013_02_28_Gesetzesentwurf.pdf.

${ }^{58}$ Bribery in order to attain a specific non-action of a parliamentarian does not seem to be covered by the proposal. However, UNCAC Art. 15 requires countries to also criminalize bribes offered or granted "in order that the official ... refrain from acting in the exercise of his or her official duties." The same goes for CLCOC Art. 4 in conjunction with Art. 2 and 3 (see Part C).

${ }^{59}$ Remarkably, the bill deals with bribery of members of foreign parliaments and international parliamentary assemblies. This might imply that Art. 2 Sect. 2 IntBestG (see Part B) will be abolished if the draft law is adopted. However, currently the attempt of bribery of foreign or international parliamentarians in international business transactions is also prohibited. Thus, on one hand the reform would extend the scope of application of the foreign bribery offense, because it would no longer be restricted to bribery "in international business transactions." But on the other hand, the criminalization of attempted bribery would be repealed. For a comparison of this draft law and other current bills mentioned above, see also Wolf, supra note 41, at 103-104.

${ }^{60}$ As Germany would still not meet all requirements of CLCOC, the Federal Government would have to declare some reservations to certain articles of this treaty. For example, trading in influence (CLCOC Art. 12) is not criminalized in Germany, and bribery in the private sector (CLCOC Art. 7 and 8 ) is only prohibited to some extent. Cf. Wolf, supra note 17 , at 792.

${ }^{61}$ Cf. Johannes C. Bockenheimer, Union streitet über Abgeordnetenbestechung, HANDELSBLATT ONLINE (2013), available at http://www.handelsblatt.com/politik/deutschland/uno-konvention-union-streitet-ueberabgeordnetenbestechung/7864454.html.

${ }^{62}$ Helmut Stoltenberg, Neuer Anlauf nach Wahl. Vorlagen zu Abgeordnetenbestechung abgelehnt, DAS PARLAMENT, July 1,2013 , at 6 .
} 
Bundestag's Committee on Legal Affairs who opposed a respective reform for many years - could not convince his parliamentary group to support the compromise proposal drafted with parliamentarians from the SPD, B'90/Die Grünen, and Die Linke. Given the separate and joint draft laws, it is rather likely that the next legislative period will finally bring a reform of Sect. 108e StGB if the SPD, B'90/Die Grünen, and Die Linke (or two out of these three parties) gain a majority in the upcoming federal election. 